\title{
Sources of nutrients driving production in the Gulf of Carpentaria, Australia - a shallow tropical shelf system
}

\author{
Michele A. Burford $^{\mathrm{a}^{*}}$, Peter C. Rothlisberg ${ }^{\mathrm{b}}$, Andy T. Revill ${ }^{\mathrm{c}}$ \\ ${ }^{a}$ Australian Rivers Institute, Griffith University, Nathan, QLD 4111, Australia \\ ${ }^{\mathrm{b} C S I R O}$ Marine \& Atmospheric Research, PO Box 120, Cleveland, QLD 4163, \\ Australia \\ ${ }^{\mathrm{c} C S I R O}$ Marine \& Atmospheric Research, GPO Box 1538, Hobart, TAS 7001, \\ Australia
}

Running header: Nitrogen processes in a tropical shelf system

${ }^{*}$ Corresponding author:

Ph: +61 737356723

Fax: +61737357615

Email: m.burford@griffith.edu.au

Address: Australian Rivers Institute, Griffith University, Nathan QLD 4111, Australia 
3 Abstract

4 The tropical Gulf of Carpentaria, Australia has recently been identified as one of the

5 world's least impacted marine areas presenting a unique opportunity to understand the

6 nutrient drivers of productivity. This study examined the nitrogen $(\mathrm{N})$ sources and

7 transformations in this pristine area, and its' role in fuelling primary productivity

8 principally based on summer data. The nitrogen budget estimates on a whole-of-Gulf

9 basis suggest that river nitrogen inputs are unlikely to be major contributors to

10 primary productivity. In the deeper waters of the Gulf, beyond the coastal boundary

11 current, the main source of nitrogen is estimated to be nitrogen fixation by

12 cyanobacteria, principally the abundant genus, Trichodesmium. Our study measured

13 high nitrogen fixation rates and depleted $\delta^{15} \mathrm{~N}$-nitrogen ratios in the particulate matter

14 in the water column during a summer bloom. During summer, bottom nitrogen

15 concentrations increased and $\delta^{15} \mathrm{~N}$-nitrogen ratios were depleted, suggesting that

16 benthic mineralization is occurring. It is therefore likely that detrital material from

17 nitrogen-rich Trichodesmium is an important contributor to benthic processes. During

18 winter, wind-driven mixing results in nitrogen from bottom waters reaching the

19 euphotic zone, and fuelling primary productivity. Therefore, Trichodesmium has an

20 important direct and indirect role in contributing to primary productivity in this

21 pristine tropical ecosystem.

22

23 Additional keywords: nitrogen fixation, Trichodesmium, nitrogen budget 


\section{Introduction}

26 Tropical coastal waters are characterized by high water temperatures and large summer rainfall events resulting in significant river inflows and associated inputs of nutrients from adjacent rivers. This contributes to high year-round primary production (Longhurst and Pauly 1987). Development of catchments for agriculture and other human activities has typically reduced or regulated river flows in many rivers, and increased nutrient loads to coastal waters (Carpenter et al. 1998; Beman et al. 2005). The increase in algal blooms worldwide, including harmful species, and development of dead zones in coastal waters has been attributed to increasing nutrient inputs from catchments (Ferber 2001; Anderson et al. 2002; Chen et al. 2007).

Further offshore, many areas of the tropics have low dissolved inorganic nitrogen $(\mathrm{N})$ concentrations and low $\mathrm{N}: \mathrm{P}$ ratios, resulting in $\mathrm{N}$ limitation. In these areas, atmospheric $\mathrm{N}$ inputs from cyanobacteria can be an important source of $\mathrm{N}$. The most studied species is the filamentous diazotroph Trichodesmium which can form large surface rafts stretching hundreds of kilometres, adding $\mathrm{N}$ to fuel productivity (Westberry and Siegal 2006). More recently, the importance of other symbiotic and small unicellular cyanobacteria in providing $\mathrm{N}$ to tropical food webs has also been established (Carpenter et al. 1999; Zehr et al. 2001; Montoya et al. 2004; Capone et

The Gulf of Carpentaria in tropical Australia is a large coastal sea $\left(330,000 \mathrm{~km}^{2}\right)$ surrounded by many large rivers seasonally providing $92,000 \mathrm{GL}$ of water to the Gulf each year during the NW monsoonal wet season (January to March). The shallow depth of the Gulf $(<70 \mathrm{~m})$ combined with the high tidal energy means that tidal and wind mixing dominates over advective processes (Forbes 1984; Wolanski and Ridd 1990). There is also relatively little mixing of waters in the Gulf with the adjacent Arafura and Coral Seas (Forbes 1984; Condie and Dunn 2006). Within the Gulf there are two distinct regions: a turbid nearshore zone at a depth of 15 to $20 \mathrm{~m}$; and deeper waters separated from the coastal zone by a boundary (buoyancy) current (Wolanski and Ridd 1990). River runoff is effectively trapped within the coastal zone. 
57 Unlike many tropical areas around the world, this region has a low human population

$58\left(<10\right.$ people $\left.\mathrm{km}^{2}\right)$ and limited human activities in the seas or catchments. It has been

59 identified as one of the least anthropogenically impacted areas globally (Halpern et al.

60 2008). However, there is increasing pressure for human development in the Gulf

61 region, including water extraction for irrigation, and regulation of water flow by

62 damming. However, the role of river nutrient inputs in promoting coastal production,

63 and their links with offshore production, remain poorly understood. In light of this,

64 this study examined the relative contribution of river $\mathrm{N}$ inputs versus $\mathrm{N}$ fixation by

65 Trichodesmium by developing a N budget for the Gulf, based on measurements in this

66 study and historical data.

67

68

\section{Materials and Methods}

69 Study Location

70 Three separate sampling trips to the Gulf of Carpentaria in the summer wet season

71 were undertaken. Voyage 1 was from 12 to 29 January 2004 and the areas sampled

72 were: the offshore waters adjacent to Albatross Bay (15 - 30 m deep); the

73 southeastern Gulf near Karumba (10 - 25 m deep); near Mornington Is. (35 - 40 m

74 deep); the Vanderlins (40 - $50 \mathrm{~m}$ deep): and Groote Eylandt (35 - $40 \mathrm{~m}$ deep) (Fig. 1,

75 Table 1). Voyage 2 was on 8 February 2005 and Albatross Bay (7 - $10 \mathrm{~m}$ deep),

76 which is within the coastal boundary layer, was sampled. Voyage 3 was between 27

77 February and 19 March 2005 and three offshore areas adjacent to Mornington Island

78 (35 - $40 \mathrm{~m}$ deep), the Vanderlins (40 - $50 \mathrm{~m}$ deep) and Groote Eylandt (35 - $40 \mathrm{~m}$

79 deep) were sampled.

80

81 The first two trips focussed on sampling the water column and sediment particulate

82 organic matter for stable isotope analyses (Table 1). Additionally, on 8 February

83 2005, infaunal samples were also taken in Albatross Bay. In the final trip, physico-

84 chemical parameters (temperature, oxygen, dissolved inorganic nutrients,

85 chlorophyll $a$ ) were sampled through the water column. Samples of particulate

86 organic matter were also taken in the water column, sediment for stable isotope

87 analyses and infaunal stable isotope analysis. Sediment box cores were also collected

88 for denitrification measurements. There was a bloom of the cyanobacterium

89 Trichodesmium during the voyage and $\mathrm{N}$ fixation incubations were done. 
$91 \quad$ Nutrients and physico-chemical parameters

92 On voyage 3 (Feb-Mar 2005) water samples were collected every $10 \mathrm{~m}$ through the

93 water column at 123 stations for nutrient analyses. Chlorophyll $a$ samples were

94 collected at 9 stations. A 12-bottle rosette of 10-L Niskin bottles was used to collect

95 water. The samples were immediately put into glass and plastic bottles. Temperature

96 and oxygen were measured continuously through the water column using a

97 conductivity-temperature-depth (CTD) logger. At the commencement of the voyage the

98 water column was thermally stratified, however, mid-way through the voyage a cyclone

99 passed through the sampling area causing the water column to be completely mixed for

100 much of the remainder of the voyage. As a result it is not valid to compare nutrient,

101 chlorophyll $a$ and other physico-chemical parameters between stations, regions and

102 depths.

103

104 Silicate, phosphate and nitrate plus nitrite concentrations were measured on board with

105 an autoanalyzer during the Gulf transects (Airey and Sandars 1987). The nitrate method

106 was modified with imidazole buffer and cleaned cadmium granules to convert nitrate to

107 nitrite. Ammonium concentrations were measured on frozen samples on shore using the

108 standard colorimetric methods (American Public Health Association 1995).

109

110 For chlorophyll analysis, known volumes of water from the surface and bottom were

111 filtered through glass fibre filters (Whatman GF/F) to trap the particulates. The filters

112 were then frozen until returned to the laboratory. Filters were extracted by probe

113 sonicating for $1 \mathrm{~min}$ in cold $100 \%$ acetone, and extracts were measured

114 spectrophotometrically after adjusting the acetone concentration to $90 \%$, when there

115 was sufficient chlorophyll, and with a spectrofluorometer when chlorophyll values were

116 low (Jeffrey and Welshmeyer 1997).

118 N fixation measurements

119 Concentrated Trichodesmium trichomes were observed in the surface waters on 2 March

120 2005. A bucket was used to sample the surface water. Subsamples were poured to

121 overflowing into twelve $250-\mathrm{mL}$ Schott bottles with sealed rubber ports in the lid.

122 Acetylene gas, pre-bubbled through water to remove contaminants, was bubbled into

123 the sample in the sealed bottles for 5 min to ensure saturation of the water with

124 acetylene. Triplicate bottles were incubated at four light levels using shade bags: $100 \%$, 
$12550 \%, 8 \%$ and $0 \%$ surface light. Samples were incubated on deck for $24 \mathrm{~h}$ in a plastic

126 tub with flow-through seawater taken near the surface. Temperature was logged

127 throughout the incubations in an additional bottle using a sensor (ETemperature, On

128 Solutions, Baulkham Hills, Australia). Water subsamples (3 mL) were withdrawn from

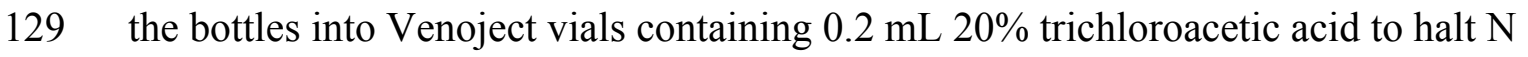

130 fixation at 0,4 and $24 \mathrm{~h}$. Subsamples were stored at $4^{\circ} \mathrm{C}$ until analyzed in the

131 laboratory. Gas from the headspace of the vials was injected into a gas chromatograph

132 with a flame ionization detector to determine the ethylene content of the samples. $\mathrm{N}$

133 fixation rates were calculated from the conversion of acetylene to ethylene (Knowles

134 1990).

136 Subsamples of water were taken at time zero $\left(\mathrm{t}_{\mathrm{o}}\right)$ for chlorophyll $a$ concentrations, algal

137 cell counts and ${ }^{15} \mathrm{~N}$-nitrogen stable isotope ratios. For chlorophyll analysis, the method

138 described above was used. For Trichodesmium cell counts, samples were fixed in 1\%

139 glutaraldehyde and kept cool until enumerated using a Sedgwick Rafter counting

140 chamber and a compound microscope (Leica) under $400 \mathrm{x}$ magnification. For stable

141 isotope analyses of Trichodesmium, triplicate water samples was filtered through

142 precombusted glass fibre filters (Whatman GF/F) to trap the particulate organic matter.

143 Filters were then frozen until returned to the laboratory. Filters were dried at $60^{\circ} \mathrm{C}$ in an

144 oven then analyzed for $\delta^{15} \mathrm{~N}$-nitrogen ratios with a continuous-flow isotope-ratio mass

145 spectrometer (Europa Tracermass and Roboprep, Crewe, England).

147 Denitrification measurements

148 Rates of denitrification were measured in the sediment using the isotope pairing

149 technique (Nielsen 1992) as described by Dalsgaard et al. (2000). Box cores were

150 taken at 29 sites across the three regions. Four sub-cores $(4.8 \mathrm{~cm} \mathrm{id} \times 30 \mathrm{~cm})$ were

151 taken from each site such that there was ca. $8 \mathrm{~cm}$ of sediment (and would be $c a$.

$15217 \mathrm{~cm}$ of water column during incubation).

154 A teflon-coated stirrer bar was then suspended $\sim 5 \mathrm{~cm}$ above the sediment. This was

155 driven by an external rotating magnet rotating at 60-70 rpm. Typically core tubes

156 from three consecutive sites were collected and incubated for each batch. Incubation

157 bins were filled with seawater such that the cores were immersed, and allowed to 


\section{Stable isotope ratios}

182 The stable isotope ratios were determined for particulate organic matter in the Gulf of 183 Carpentaria in January 2004 and February/March 2005. The following regions were 184 sampled: near Karumba; near Mornington Island; the Vanderlins; Groote Eylandt, and 185

equilibrate for $6 \mathrm{~h}$ or more. After equilibration, the water level was reduced to below core tube height and experiments commenced with the addition of stock ${ }^{15} \mathrm{~N}$-nitrate to a concentration of $60 \mu \mathrm{M}$. This concentration was assumed to be a saturating concentration based on studies by Cook et al. (2004). The water in each core was stirred for $20 \mathrm{~min}$ and sub-samples taken for the analysis of nitrate in order to calculate the final ${ }^{15} \mathrm{~N}$ enrichment. Cores were then capped with sealed Perspex lids and incubated in the dark in flowing seawater. Cores were sacrificed at $0,1.4,2.5,4.5$ and $6 \mathrm{~h}$. At each time point, $1 \mathrm{~mL}$ of $50 \%$ zinc chloride was added to the water overlying the sediment before the sediment was gently slurried with the water column using a metal rod, coarser particles were allowed to settle for about a minute before a subsample was taken using a gas tight syringe. The sample was then placed in a 12.5 $\mathrm{mL}$ Exetainer (Labco, High Wycombe, UK) to which $250 \mu \mathrm{L}$ of $50 \% \mathrm{w} / \mathrm{v}$ zinc chloride had been added and stored at $4^{\circ} \mathrm{C}$ until returned to the laboratory.

A headspace of helium was introduced into the Exetainer within 2 weeks and the samples were then analyzed within several months. Headspace analysis for ${ }^{28} \mathrm{~N}_{2^{-}}$, ${ }^{29} \mathrm{~N}_{2}$ - and ${ }^{30} \mathrm{~N}_{2}$-nitrogen gas was carried out by removing a $50 \mu 1$ sample in a gas tight syringe and injecting into a gas chromatograph (5890 Hewlett Packard) in line with an isotope ratio mass spectrometer (Finnigan MAT delta S). A copper reduction column heated to $640^{\circ} \mathrm{C}$ was used to remove oxygen from the sample, carbon dioxide and water were removed using a liquid $\mathrm{N}$ cryotrap. Denitrification rates were calculated according to the isotope pairing equations in Dalsgaard et al. (2000). Albatross Bay (inshore, offshore) (Fig. 1, Table 1). For stable isotope analyses in particulate material, triplicate water samples from the surface were filtered through precombusted glass fibre filters (Whatman GF/F) to trap the particulate organic matter. In the case of the third voyage, bottom water samples were also taken and filtered. Filters were then frozen until returned to the laboratory. Filters were dried at $60^{\circ} \mathrm{C}$ and 
190

191

192

193 For sediment stable isotope ratios, box cores were taken at 48 sites across three regions

194 (Mornington Island, Vanderlins, Groote Eylandt). Three small cores (31 mm dia.) were

195 taken from one box core at each site for measurement of ${ }^{15} \mathrm{~N}$-nitrogen stable isotope

196 ratios. The sediment was extruded from the core to maintain the integrity of the surface

197 and the top $10 \mathrm{~mm}$ sliced off the top. This was frozen until analyzed in the laboratory.

198 Marine sediments are screened through a wire mesh screen to remove rocks and rubble,

199 dried at $60^{\circ} \mathrm{C}$ and ground before being analyzed for $\delta^{15} \mathrm{~N}$-nitrogen ratios with a

200 continuous-flow isotope-ratio mass spectrometer (Europa Tracermass and Roboprep,

201 Crewe, England).

202

203 Grab sediment cores were taken at five sites near Karumba, Groote Eylandt and

204 Albatross Bay offshore in January 2004. Mini-cores were inserted into the surface of

205 the sediment and the sediment was extruded from the core to maintain the integrity of

206 the surface and the top $1 \mathrm{~cm}$ sliced off the top. The sediment was processed and

207 analyzed as above.

In February 2005, sediment grabs were also collected at four sites in Albatross Bay for analysis of the stable isotope ratios of infauna. Sediment samples were frozen until analysed. Thawed samples were sieved onto $500-\mu \mathrm{m}$ sieves and infauna separated from remaining sediment/sand particles under a stereo-microscope. Infauna consisted of crustaceans, molluscs, small fish, and polychaete worms. Molluscs were removed from their shells prior to analysis. All samples were dried at $60^{\circ} \mathrm{C}$ until completely dried, then ground to a fine powder with a mortar and pestle before being analyzed for $\delta^{15} \mathrm{~N}$ nitrogen ratios with a continuous-flow isotope-ratio mass spectrometer (Europa Tracermass and Roboprep, Crewe, England). Mean ${ }^{13} \mathrm{C}$-carbon and ${ }^{15} \mathrm{~N}$-nitrogen ratios were determined.

In February/March 2005, three sediment box cores were also taken in each of three regions, Mornington Island, Vanderlins, and Groote Eylandt, for analysis of the stable isotope ratios for infauna. Whole box core samples were sieved onto a $500 \mu \mathrm{m}$ sieve 
223 with water, and the trapped organisms stored frozen until analysed. In the laboratory,

224 samples were thawed, and infauna separated from remaining sediment/sand particles.

225 Analysis was conducted as described above and mean ${ }^{13} \mathrm{C}$-carbon and ${ }^{15} \mathrm{~N}$-nitrogen

226 ratios for each region were determined.

$228 \quad$ N budget

229 The results of this study were combined with historical data on the oceanography of the

230 Gulf of Carpentaria to generate a $\mathrm{N}$ budget for the Gulf of Carpentaria. The area of the

231 Gulf was assumed to be $330,000 \mathrm{~km}^{2}$, with an average depth of $43.4 \mathrm{~m}$, resulting in a

232 volume of $1.4 \times 10^{13} \mathrm{~m}^{3}$. The total pools of nitrate and ammonium in the water column

233 of the Gulf were calculated based on concentrations in this as well as previous studies

234 (Rothlisberg et al. 1989; Rothlisberg et al. 1994; Burford and Rothlisberg 1999; this

235 study). Annual nitrate and ammonium uptake rates by phytoplankton were determined

236 using the ${ }^{15} \mathrm{~N}$-nitrogen uptake data of Burford and Rothlisberg (1999). Annual areal N

237 fixation by Trichodesmium was determined using the depth-integrated $\mathrm{N}$ fixation rates

238 for a Trichodesmium bloom measured in this study, and assuming a bloom depth of $1 \mathrm{~m}$.

239 The calculated rates were within the range determined by Capone et al. (2005) for the

240 northern Atlantic Ocean. It was assumed that Trichodesmium was fixing $\mathrm{N}$ at the

241 calculated rates a third of a year, based on a previous study of the relative abundance of

242 Trichodesmium in the Gulf (Burford et al. 1995).

244 Annual N fixation rates in the seagrass beds were determined by Moriarty et al. (1990).

245 A spatial coverage of seagrass of 52,000 ha was used based on Roelofs et al. (2005).

246 Annual denitrification rates were determined based on this study. River inflows were

247 based on multiplying by total $\mathrm{N}$ concentrations in the water column for the Embley,

248 Flinders, Norman and Gregory Rivers (20.7, 66.2, 24.0 and 21.7 $\mu \mathrm{M} N$ respectively, $\mathrm{M}$.

249 Burford, unpubl. data) by the annual river flow volumes (www.nrw.qld.gov.au/) for

250 those rivers (A. Brooks, unpubl. data). For the other 25 largest rivers in the Gulf, a

251 mean total $\mathrm{N}$ concentration based on the other four rivers was used. All loads were

252 summed to give a total river $\mathrm{N}$ input to the Gulf.

\section{Results}

255 In February 2005, mean ammonium, oxides of N, phosphate and silicate

256 concentrations did not vary across three regions (Mornington Is., Vanderlins, Groote 
257 Eylandt) but Groote Eylandt had higher variability in nitrate concentrations than the 258 other two sites (Fig. 2). Chlorophyll $a$ concentrations were $0.80 \pm 0.45$ (SD) $\mu g \mathrm{~L}^{-1}$ 259 and did not show any trends between regions.

261 Rate measurements

262 Denitrification rates measured during the study were $0.033 \pm 0.054$ (SD) $\mu \mathrm{mol} \mathrm{m} \mathrm{m}^{-2} \mathrm{~h}^{-1}$ 263 in the Groote Eylandt region, $0.007 \pm 0.010$ (SD) $\mu \mathrm{mol} \mathrm{m} \mathrm{m}^{-2} \mathrm{~h}^{-1}$ in Mornington Is. 264 region and $0.016 \pm 0.027(\mathrm{SD}) \mu \mathrm{mol} \mathrm{m}^{-2} \mathrm{~h}^{-1}$ in the Vanderlins region. The variability 265 between stations was high since the rates were close to the detection limit for the 266 method. At many stations, denitrification rates were below the detection limit.

The $\mathrm{N}$ fixation rate was determined during a surface Trichodesmium bloom $(3,400$ trichomes $\mathrm{mL}^{-1}$ ) in the Mornington Island region in February 2005. N fixation rates were highest when samples were incubated at $50 \%$ surface light $\left(76 \mu \mathrm{mol} \mathrm{N} \mathrm{m} \mathrm{h}^{-2}\right)$

271 compared with $8 \%\left(42 \mu \mathrm{mol} \mathrm{N} \mathrm{m}^{-2} \mathrm{~h}^{-1}\right)$ and $100 \%\left(27 \mu \mathrm{mol} \mathrm{N} \mathrm{m}^{-2} \mathrm{~h}^{-1}\right)$ light. The 272 depth-integrated $\mathrm{N}$ fixation assuming a $1 \mathrm{~m}$ deep surface bloom was $578 \mu \mathrm{mol} \mathrm{N} \mathrm{m}{ }^{-2}$

$273 \mathrm{~d}^{-1}$. The $\delta^{15} \mathrm{~N}$ ratios of Trichodesmium during the bloom, and particulate matter in the 274 water column throughout the February/March 2005 voyage were close to 0 to $1 \%$ 275 while the molar C:N ratios were between 3 and 5 (Fig. 3). These values were 276 compared with a previous Gulf voyage in January 2004 when no Trichodesmium 277 bloom was apparent. The $\delta^{15} \mathrm{~N}$ ratio at a range of sites was substantially higher, 5 to $2786.5 \%$, as was the $\mathrm{C}: \mathrm{N}$ ratio (6.5 to 9$)$.

280 Stable isotope ratios for sediment and infauna

281 The $\delta^{15} \mathrm{~N}$ ratio was also measured in the sediment during the Trichodesmium bloom in 282 February/March 2005 with values ranging from 2.4 to 3.7 \%o (Fig. 4). This compared 283 with values ranging from 3.9 to $6.0 \%$ during two previous Gulf voyages in January 2842004 and 2005 when no Trichodesmium blooms were apparent. Infaunal $\delta^{15} \mathrm{~N}$ ratios 285 were compared with ratios in particulate organic matter in the water column in both a 286 period of Trichodesmium bloom in the southern Gulf (February/March 2005) and a 287 non-bloom period in the northeastern Gulf (January 2005) (Fig. 5). There were a 288 wide range of $\delta^{15} \mathrm{~N}$ ratios for the infauna but no obvious differences between the two 289 sampling periods. In contrast, the $\delta^{15} \mathrm{~N}$ ratios for the particulate organic matter were 
314 This study is a first attempt to determine a $\mathrm{N}$ budget for the Gulf of Carpentaria,

315 Australia. Our study supports previous studies that suggest that the Gulf is N limited

substantially different between the northeast Gulf in January 2005, and the southern Gulf in February/March 2005.

\section{Discussion}

\section{N budget}

The data from this study were combined with data from previous studies in the Gulf to produce a Gulf-wide N budget (Table 3). The nitrate pool in the Gulf was higher than the ammonium pool, $75 \mathrm{Mt}$ compared with $24 \mathrm{Mt}$, with nitrate taken up more rapidly by phytoplankton than ammonium (Table 3) (Rothlisberg et al. 1989; Rothlisberg et al. 1994; Burford and Rothlisberg 1999). However, much of the nitrate was present in bottom waters and therefore during periods of stratification would not be available to phytoplankton.

The importance of $\mathrm{N}$ fixation was determined using two methods: direct measurement of $\mathrm{N}$ fixation during a bloom of Trichodesmium, and measurement of $\delta^{15} \mathrm{~N}$ stable isotope ratios in the water column and sediment. $\mathrm{N}$ fixation from Trichodesmium was calculated to be a substantial new source of $\mathrm{N}$ into the Gulf added at a rate similar to nitrate and ammonium uptake (290 Mt y $\mathrm{y}^{-1}$ compared with 390 and $260 \mathrm{Mt} \mathrm{y}^{-1}$ respectively) (Burford and Rothlisberg 1999). River loads of $N$ were calculated to be substantially lower, i.e. $43 \mathrm{Mt} \mathrm{y}^{-1}$, comparable with inputs of new $\mathrm{N}$ via $\mathrm{N}$ fixation in the seagrass beds. In contrast, loss of $\mathrm{N}$ via denitrification rates measured was low relative to inputs, i.e. $11 \mathrm{Mt}^{-1}$. Overall $\mathrm{N}$ inputs to the Gulf were substantially higher than $\mathrm{N}$ outputs. with rapid cycling of N (Rothlisberg et al. 1989; Rothlisberg et al. 1994; Burford and Rothlisberg 1999). Dissolved inorganic N:phosphorus ratios and dissolved inorganic $\mathrm{N}$ concentrations were low. Previous studies in the Gulf have also shown a response of phytoplankton to N, but not phosphorus addition (Burford and Rothlisberg 1999), and the prevalence of the $\mathrm{N}$-fixing cyanobacteria, Trichodesmium, which typically dominates in low $\mathrm{N}$ environments (Burford et al. 1995). A study of the northwest 
322 shelf region of Australia also showed N limitation with rapid cycling of $\mathrm{N}$ (Furnas and

323 Mitchell 1999).

325 Additionally, this study showed that denitrification rates were low compared with 326 other studies in coastal waters, i.e. the tropical Great Barrier Reef, the eutrophic Gulf 327 of Gdansk and the upwelling regions off Chile (Witek et al. 2003; Molina et al. 2004; 328 Alongi and McKinnon 2005; Alongi et al. 2007). These low rates may reflect low 329 nitrate availability consistent with a N-limited system. N limitation in the Gulf 330 parallels findings in other marine waters around Australia (Condie and Dunn 2006).

\section{$332 \quad$ River inputs}

333 River inputs are not major contributors of $\mathrm{N}$ on a whole-of-Gulf scale. However, 334 coastal runoff is trapped within the coastal boundary layer to a water depth of 335 approximately $20 \mathrm{~m}$ (Wolanski and Ridd 1990). This coastal area is approximately $33620 \%$ of the area of the Gulf. In this context, river N inputs, particularly in the 337 southern Gulf where most of the large rivers occur, may play a more important role in 338 fuelling coastal productivity. Alongi and McKinnon (2005) found that terrestrially339 derived nutrients were efficiently utilised by benthic and pelagic microbes in the 340 coastal zone in the Great Barrier Reef shelf, in northern Australia reducing their 341 impact offshore. It is likely that similar processes are underway in the Gulf of

342 Carpentaria. Within the coastal boundary layer of the Gulf there is a net movement of 343 water from east to west in the Gulf, with water ultimately entering the western 344 Arafura Sea, rather than mixing with the central Gulf. The coastal area of the Gulf is 345 dominated by vast highly productive seagrass beds (Moriarty et al. 1990; Roelofs et 346 al. 2005). These provide an important food source for biota, including commercially 347 important shrimp species (Loneragan et al. 1997). Estimated river $\mathrm{N}$ inputs were 348 comparable with $\mathrm{N}$ fixation in the seagrass beds (Moriarty and O'Donohue 1993) 349 suggesting that these inputs may provide an important source to fuel seagrass and 350 epiphyte production.

352 Although $\mathrm{N}$ from river sources may be important to coastal production, the presence 353 of the coastal boundary current means that it is likely that little of this source of $\mathrm{N}$ is 354 likely to reach the deeper waters of the Gulf. Previous studies have not tracked 355 riverine $\mathrm{N}$ offshore, but studies of $\delta^{13} \mathrm{C}$ ratios in particulate organic matter throughout 
356 the deeper waters of Gulf which found no evidence of a terrestrial signal (Rothlisberg

357 et al. 1994; Burford, unpubl. data). Additionally, a study of food sources for estuarine

358 shrimp in the Gulf showed no evidence that mangrove and terrestrial carbon exported

359 from estuaries contributing to offshore food webs (Loneragan et al. 1997).

360

$361 \quad$ N fixation

362 This study has shown that $\mathrm{N}$ fixation can be a significant process in the Gulf, as

363 demonstrated by measurement of high rates of fixation and the depleted $\delta^{15} \mathrm{~N}$ ratios in

364 the particulate matter in the water column during a Trichodesmium bloom. Previous

365 studies in the Gulf have shown the net phytoplankton community is comprised

366 principally of the N-fixing cyanobacteria Trichodesmium and large diatoms

367 (Hallegraeff and Jeffrey 1984; Rothlisberg et al. 1994; Burford et al. 1995), and that

368 primary productivity rates are relatively high, particularly in summer months (Motoda

369 et al. 1978; Rothlisberg et al. 1994; Burford et al. 1999). Previous work has also

370 shown that chlorophyll $a$ concentrations are higher in summer than winter but only in

371 inshore regions (Burford et al. 1995). Further offshore, chlorophyll a remains similar

372 year-round, typically less than $<1 \mu \mathrm{g} \mathrm{L}^{-1}$. Trichodesmium is numerically most

373 dominant in the summer months when stratification occurs (Burford et al. 1995).

375 Conservative assumptions about the annual rates of $\mathrm{N}$ fixation from data in our study

376 were made based on the information in seasonal abundance (Burford et al. 1995).

377 Rates of N fixation measured in February/March 2005 during a Trichodesmium bloom

378 (3,400 trichomes $L^{-1}$ in surface waters) were comparable with those in other tropical

379 waters (Capone et al. 2005). More recently, Trichodesmium has been shown to be

380 more abundant at depth than previously thought due to sampling artefacts (Davis and

381 McGillicuddy 2006). Therefore it is likely that rates may be significantly higher than

382 previously thought. In contrast with some other tropical areas, the main factor likely

383 to be limiting Trichodesmium growth in the Gulf of Carpentaria is iron rather than

384 phosphorus availability (Sohm et al. 2006, 2008). Aeolian dust from central Australia

385 has been shown to provide an important source of iron for diazotrophs in Australian

386 coastal waters (Shaw et al. 2008). 
388 The rates of $\mathrm{N}$ fixation for the Gulf do not take into account the role of $\mathrm{N}$-fixing

389 symbiotic cyanobacteria typically associated with diatoms, and small unicellular

390 cyanobacteria which have recently been shown to contribute significantly to global $\mathrm{N}$

391 fixation rates (Carpenter et al. 1999; Zehr et al. 2001; Montoya et al. 2004; Capone et

392 al. 2006). Previous studies in the Gulf have shown that diatoms with symbionts are

393 numerically dominant, e.g. Rhizosolenia with Richelia (Burford et al. 1995).

394 Therefore, $\mathrm{N}$ inputs from fixation are likely to be higher than the estimates calculated 395 from this study.

397 Previous studies have shown that Trichodesmium is poorly grazed by zooplankton 398 (Mulholland 2007). Studies in the Gulf have also shown that it is a poor nutritional 399 source for shrimp larvae because the sheath surrounding the trichome is difficult to 400 digest, resulting in the passing of intact trichomes through the gut. (Preston et al. 401 1998). However, Trichodesmium may contribute to $\mathrm{N}$ cycling via release of dissolved 402 organic N and ammonium from cells (Glibert and Bronk 1994; Mulholland 2007) or 403 viral lysis (Hewson et al. 2004). The released $\mathrm{N}$ has been shown to promote the 404 growth of diatoms (Agawin et al. 2007). Alternatively the detrital material may be 405 deposited on the sediment as it senesces. In our study, $\delta^{15} \mathrm{~N}$ ratios were lower in the 406 sediment during a Trichodesmium bloom compared with non-bloom periods. Other 407 studies have found isotopically light $\delta^{15} \mathrm{~N}$ ratios in sediment traps and sediment during 408 Trichodesmium blooms (Capone et al. 1998; Knapp et al. 2005). Infaunal $\delta^{15} \mathrm{~N}$ ratios 409 were not depleted during this time, suggesting that detrital material from the bloom 410 was not substantially grazed by infauna and is therefore likely to be subject to 411 microbial degradation.

413 During periods of water column stratification, particularly during summer months 414 when wind mixing is low, nitrate can be higher in bottom waters (Rothlisberg et al. 415 1989; Rothlisberg et al. 1994; this study). This suggests that nitrification is occurring 416 in or near the sediment. It is likely that deposition of N-rich cyanobacterial detritus 417 generated from $\mathrm{N}$ fixation is an important source of $\mathrm{N}$ fuelling these bacterial 418 processes. During winter months when the wind strength increases, the water column 419 may become completely mixed and dissolved inorganic $\mathrm{N}$ from bottom waters 420 becomes evenly distributed through the water column (Burford and Rothlisberg 
421 1999). Therefore atmospheric $\mathrm{N}$ inputs via $\mathrm{N}$-fixing cyanobacteria may create a

422 coupling between water column and sediment processes, and hence also fuel primary

423 productivity.

425 Water exchange

426 Net exchange of nutrients from the Arafura Sea is unlikely to be substantial given the 427 similarity in the nutrient concentrations in the Gulf, Arafura Sea and the Torres Strait 428 (Condie and Dunn 2006; M. Furnas, unpubl. data). Indeed, the deeper waters of the 429 Gulf and the Arafura Sea have been classified within the same biogeographical region 430 based on their physico-chemical and primary productivity characteristics (Condie and 431 Dunn 2006). Additionally, water circulates around a central gyre in the Gulf meaning 432 that the water residence time in the deeper waters of the Gulf is in the order of $3 \mathrm{y}$ 433 (Wolanski and Ridd 1990; Condie and Dunn 2006). The relatively low exchange of 434 water in the northern Gulf, lack of difference between $\mathrm{N}$ concentrations entering and 435 leaving the Gulf and low rates of denitrification mean that little $\mathrm{N}$ is likely to be lost 436 from the system. Overall inputs of $\mathrm{N}$ were higher than outputs. It may be that $\mathrm{N}$ is 437 accumulating or alternatively that $\mathrm{N}$ losses have been underestimated. A number of 438 processes were not measured directly, such as anammox (anaerobic ammonium 439 oxidation), which may have resulted in $\mathrm{N}$ removal.

441 The Gulf is a relatively pristine ecosystem, with the main nutrient inputs in the 442 catchment likely to be from natural erosion processes, and low intensity agriculture 443 (principally cattle grazing). Future agricultural development is proposed for the Gulf 444 catchments including damming of rivers and irrigated intensive agriculture, e.g. 445 ponded pastures and cotton production. Damming of rivers and regulation of flow 446 may reduce nutrient loads hence reducing coastal production and negatively 447 impacting on coastal fisheries. Conversely intensive forms of agriculture are likely to 448 increase nutrient loads, in turn increasing estuarine and coastal production until a 449 threshold is reached when ecosystem health declines as evidenced by anoxia and algal 450 blooms.

452 In summary, this study has shown that productivity in the Gulf of Carpentaria is likely 453 to be limited by $\mathrm{N}$ availability. In the deeper waters, the diazotroph Trichodesmium is 454 likely to be an important source of new $\mathrm{N}$ as demonstrated diagrammatically (Fig. 6). 
455 In shallow waters, $\mathrm{N}$ fixation and river inputs are likely to be relatively more

456 important. It is proposed that $\mathrm{N}$ fixed by Trichodesmium enters the food web via the 457 detrital pathway rather than directly by consumption by higher trophic levels. 458 
459

460 Acknowledgements

461 We wish to acknowledge the help of the captain and crew of the RV Southern

462 Surveyor and FV Flinders Pearl, Robert Pendrey, Frank Coman, Andrew Cook and

463 Catherine Leigh in undertaking field sampling, Neale Johnson undertook the nutrient

464 analyses, Jason Kerr measured ethylene production, Scott Condie and Eric Wolanski

465 provided data on physical processes in the Gulf, Andrew Brooks provided river flow

466 rate data, Wayne Rochester provided data and data management expertise, Catherine

467 Leigh provided a figure, Miles Furnas provided nutrient data from Torres Strait, and

468 Scott Condie and one anonymous reviewer provided comments on the manuscript. 
469

470

471

472

473

474

475

476

477

478

479

480

481

482

483

484

485

486

487

488

489

490

491

492

493

494

495

496

497 498

499

500

501

\section{References}

Agawin, N.S.R., Rabouille, S., Veldhuis, M.J.W., Servatius, L., Hol, S., et al. (2007)

Competition and facilitation between unicellular nitrogen-fixing cyanobacteria and non-nitrogen-fixing phytoplankton species. Limnology and Oceanography 52, 2233 2248.

Airey, D. and Sandars, G. (1987) Automated analysis of nutrients in seawater.

(Commonwealth Scientific and Industrial Research Organisation (Australia), Marine Laboratories Report No. 166).

Alongi, D.M. and McKinnon, A.D. (2005) The cycling and fate of terrestrially-derived sediments and nutrients in the coastal zone of the Great Barrier Reef shelf. Marine Pollution Bulletin 51, 239-252.

Alongi, D.M., Trott, L.A. and Pfitzner, J. (2007) Deposition, mineralization, and storage of carbon and nitrogen in sediments of the far northern and northern Great Barrier Reef shelf. Continental Shelf Research, 27, 2595-2622.

American Public Health Association. (1995) Standard Methods for the Examination of Water and Wastewater. 20th Edition, (Eds A.E., Greenburg, L.S. Clesceri and A.D, Eaton) (American Public Health Association: Washington, D.C.).

Anderson, D.M., Glibert, P.M. and Burkholder, J.M. (2002) Harmful algal booms and eutrophication: Nutrient sources, composition and consequences. Estuaries 25, 704726.

Beman, J.M., Arrigo, K.R. and Matson, P.A. (2005) Agricultural runoff fuels large phytoplankton blooms in vulnerable areas of the ocean. Nature 434, 211-214

Burford, M.A. and Rothlisberg, P.C. (1999) Factors limiting phytoplankton production in a tropical continental shelf ecosystem. Estuarine, Coastal and Shelf Science 48, 541-549.

Burford, M.A., Rothlisberg, P.C. and Wang, Y. (1995) Spatial and temporal distribution of tropical phytoplankton species and biomass in the Gulf of Carpentaria, Australia. Marine Ecology Progress Series 118, 255-266

Capone, D.G., Subramaniam, S., Montoya, J.P., Voss, M., Humborg, C. et al. (1998) An extensive bloom of the $\mathrm{N}_{2}$-fixing cyanobacterium Trichodesmium erythraeum in the central Arabian Sea. Marine Ecology Progress Series 172, 281-292.

Capone, D.G., Burns, J.A., Montoya, J.P., Subramaniam, J., Mahaffey, C., et al. (2005) Nitrogen fixation by Trichodesmium spp.: An important source of new 
nitrogen to the tropical and subtropical North Atlantic Ocean. Global Biogeochemical Cycles 19: GB2024, doi: 10.1029/2004GB002331.

Capone, D.G., Subramaniam, S. and Carpenter, E.J. (2006) Nitrogen fixation by diazotroph-diatom associations: a nitrogen input amplifier in the open ocean. EOS Transactions of the American Geophysical Union 87, No. 36 supplement. Carpenter, S.R., Caraco, N.F., Correll, D.L., Howarth, R.W., Sharpley, A.N. et al. (1998) Nonpoint pollution of surface waters with phosphorus and nitrogen. Ecological Applications 8, 559-568.

Carpenter, E.J., Montoya, J.P., Burns, J., Mulholland, M.R., Subramaniam, A. et al. (1999) Extensive bloom of an $\mathrm{N}_{2}$-fixing diatom/cyanobacterial association in the tropical Atlantic Ocean. Marine Ecology Progress Series 185, 273-283.

Chen, C-C., Gong, G-C. and Shiah, F-K. (2007) Hypoxia in the East China Sea: One of the largest coastal low-oxygen areas in the world. Marine Environmental Research 64, 399-408.

Condie, S.A. and Dunn, J.R. (2006) Seasonal characteristics of the surface mixed layer in the Australasian region: implications for primary production regimes and biogeography. Marine and Freshwater Research 57, 569-590.

Cook, P. L. M., Revill, A. T., Butler, E.C.V. and Eyre, B.D. (2004) Carbon and nitrogen cycling on intertidal mudflats of a temperate Australian estuary. II. Nitrogen cycling. Marine Ecology Progress Series 280, 39-54.

Dalsgaard, T., Nielsen, L.P., Brotas, V., Viaroli, P., Underwood, G., et al. (2000) Protocol handbook for NICE - Nitrogen Cycling in Estuaries: a project under the EU research programme: Marine Science and Technology (MAST III), National Environmental Research Institute, Silkeborg, Denmark.

Davis, C.S. and McGillicuddy, D.J. (2006) Transatlantic abundance of the $\mathrm{N}_{2}$-fixing colonial cyanobacterium Trichodesmium. Science 312, 1517-1519.

Ferber, D. (2001) Keeping the stygian waters at bay. Science 291, 968-973.

Forbes, A.M.G. (1984) The contribution of local processes to seasonal hydrology of the Gulf of Carpentaria. Océanographe Tropicale 19, 193-201.

Furnas, M.J. and Mitchell, A.W. (1999) Wintertime carbon and nitrogen fluxes on Australia's Northwest Shelf. Estuarine, Coastal and Shelf Science 49, 165-175.

Glibert, P.M. and Bronk, D.A. (1994) Release of dissolved organic nitrogen by marine diazotrophic cyanobacteria, Trichodesmium spp. Applied and Environmental Microbiology 60, 3996-4000. 
536 Hallegraeff, G.M. and Jeffrey, S.W. (1984) Tropical phytoplankton species and pigments of continental shelf waters of North and North-West Australia. Marine Ecology Progress Series 20, 59-74.

Halpern, B.S., Walbridge, S., Selkoe, K.A., Kappel, C.V., Micheli, F., et al. (2008) A global map of human impact on marine ecosystems. Science 319, 948-952.

Hewson, I., Govil, S.R., Capone, D.G., Carpenter, E.J. and Fuhrman, J.A. (2004) Evidence of Trichodesmium viral lysis and potential significance for biogochemical cycling in the oligotrophic ocean. Aquatic Microbial Ecology 36, 1-8.

Jeffrey, S.W. and Welshmeyer, N.A. (1997) Spectrophotometric and fluorometric equations in common use in oceanography. In 'Phytoplankton Pigments in Oceanography' (Eds S.W. Jeffrey, R.F.C. Mantoura, and S.W. Wright) (Monographs on Oceanographic Methodology No.10. UNESCO Publication).

Knapp, A.N., Sigman, D.M. and Lipschultz, F. (2005) N isotopic composition of dissolved organic nitrogen and nitrate at the Bermuda Atlantic time series study site. Global Biogeochemical Cycles 19: GB1018, doi:10.1029/2004GB002320.

Knowles R. (1990) Acetylene inhibition techniques: Development, advantages, and potential problems. In: Denitrification in Soil and Sediment. (Eds. N.P. Revsbech, and J. Sørensen) pp. 151-166 (Plenum Press, New York).

Loneragan, N.R., Bunn, S.E. and Kellaway, D.M. (1997) Are mangroves and seagrasses sources of organic carbon for penaeid prawns in a tropical Australian estuary? A multiple stable-isotope study. Marine Biology 130, 289-300.

Longhurst, A.R. and Pauly, D. (1987) Ecology of Tropical Oceans. (Academic Press, San Diego).

Molina, V., Farias, L., Graco, M., Rivera, C., Pinto, L. et al. (2004) Benthic nitrogen regeneration under oxygen and organic matter spatial variability off Concepcion ( $\left.\sim 36^{\circ} \mathrm{S}\right)$, central Chile. Deep-Sea Research II 51, 2507-2522.

Moriarty, D.J.W., Roberts, D.G. and Pollard, P.C. (1990) Primary and bacterial productivity of tropical seagrass communities in the Gulf of Carpentaria, Australia. Marine Ecology Progress Series 61, 145-157. 
Moriarty, D.J.W. and O’Donohue, M.J. (1993) Nitrogen fixation in seagrass communities during summer in the Gulf of Carpentaria, Australia. Australian Journal of Marine and Freshwater Research 44, 117-125.

Motoda, S., Kawamura, T. and Taniguchi, A. (1978) Differences in productivities between the Great Australian Bight and the Gulf of Carpentaria, Australia, in summer. Marine Biology (Berlin) 46, 93-99.

Mulholland, M.R. (2007) The fate of nitrogen fixed by diazotrophs in the ocean. Biogeosciences 4, 37-51.

Nielsen, L.P. (1992) Denitrification in sediment determined from nitrogen isotope pairing. FEMS Microbiology and Ecology 86, 357-362

Preston, N.P., Burford, M.A. and Stenzel, D. (1998) Effects of Trichodesmium spp. blooms on penaeid prawn larvae. Marine Biology 131, 671-679.

Roelofs, A., Coles, R. and Smit, N. (2005) A survey of intertidal seagrass from Van Diemen Gulf to Castlereagh Bay, Northern Territory, and from Gove to Horn Island, Queensland. Report to the National Oceans Office. Department of the Environment and Heritage, Australian Government.

Rothlisberg, P.C., White, N.J. and Forbes, A.M.G. (1989) Hydrographic atlas of the Gulf of Carpentaria. CSIRO Marine Laboratories Report No. 209.

Rothlisberg, P.C., Pollard, P.C., Nichols, P.D., Moriarty, D.J.W., Forbes, A.M.G., et al. (1994) Phytoplankton community structure and productivity in relation to the hydrological regime of the Gulf of Carpentaria, Australia, in summer. Australian Journal of Marine and Freshwater Research 45, 265-282.

Shaw, E.C., Gabric, A.J. and McTainsh, G.H. (2008) Impacts of aeolian dust deposition on phytoplankton dynamics in Queensland coastal waters. Marine and Freshwater Research 59, 951-962.

Sohm, J.A., Mahaffey, C. and Capone, D.G. (2006) Assessment of relative phosphorus limitation of Trichodesmium in the North Pacific and Atlantic and the north coast of Australia. EOS Transactions of the American Geophysical Union 87, No. 36 supplement.

Sohm, J.A., Mahaffey, C. and Capone, D.G. (2008) Assessment of relative phosphorus limitation of Trichodesmium spp. In the North Pacific, North Atlantic, and the north coast of Australia. Limnology and Oceanography 53, 2495-2502. 
601 Westberry, T.K. and Siegal, D.A. (2006) Spatial and temporal distribution of

602

603

604

605

606

607

608

609

610

611

612
Trichodesmium blooms in the world's ocean. Global Biogeochemical Cycles 20: GB2024, doi: 10.1029/2005GB002673.

Witek, Z., Humborg, C., Savchuk, O., Grelowski, A. and Łysiak-Pastuszak, E. (2003) Nitrogen and phosphorus budgets of the Gulf of Gdańsk. Estuarine, Coastal and Shelf Science 57, 239-248.

Wolanski, E. and Ridd, P. (1990) Mixing and trapping in Australian coastal waters. In Coastal and Estuarine Studies Vol. 38, (ed. Cheng, R. T.) (Springer-Verlag, New York) pp. 165-183.

Zehr, J.P., Waterbury, J.B., Turner, P.J., Montoya, J.P., Omoregle, E., et al. (2001) Unicellular cyanobacteria fix $\mathrm{N}_{2}$ in the subtropical North Pacific Ocean. Nature 412, 635-638. 


\section{Figure Legend}

614 Figure 1: Map showing study areas in the Gulf for the three voyages.

615

616 Figure 2: (a) Mean $( \pm \mathrm{SD})$ phosphate, nitrate, ammonia, and (b) silicate concentrations

$617(\mu \mathrm{M})$ in each region during voyage 3 in 2005.

618

619 Figure 3: $\delta^{15} \mathrm{~N}$-nitrogen ratios $( \pm \mathrm{SD})$ in the particulate organic matter (open squares)

620 and Trichodesmium (closed squares) in the water column during a Trichodesmium

621 bloom in the Vanderlins, Groote Eylandt and Mornington Island regions in

622 February/March 2005, and during a non-bloom period in the Vanderlins, Groote

623 Eylandt, Mornington Island, Karumba and Albatross Bay offshore regions in January

6242004 (closed diamonds) in the Gulf of Carpentaria

625

626 Figure 4: $\delta^{15} \mathrm{~N}$-nitrogen ratios $( \pm \mathrm{SD})$ in the sediment on three separate sampling 627 occasions in the Gulf of Carpentaria. $\mathrm{Ka}=$ Karumba region, $\mathrm{Gr}=$ Groote Eylandt

628 region, $\mathrm{We}=$ Weipa offshore region, $\mathrm{AB}=$ Albatross Bay, $\mathrm{Va}=$ Vanderlins region,

629 Mo $=$ Mornington Island region.

630

631 Figure 5: Comparison of the mean $\delta^{15} \mathrm{~N}$-nitrogen ratios $( \pm \mathrm{SD})$ of particulate organic

632 matter and infauna in Albatross Bay, 4 sites, January 2005 (closed diamonds) and in

633 Vanderlins (open circle), Groote Eylandt (open triangle) and Mornington Island

634 (closed square) regions (3 sites in each region) February/March 2005 (open squares). 635

636 Figure 6: Schematic diagram showing the two zones in the Gulf: coastal waters and

637 deeper waters, separated by a coastal boundary layer. The main direction of flow

638 (black arrows) is shown in these two zones. Additionally, major sources of new $\mathrm{N}$ in

639 the form of nitrogen fixation by plants (grey arrows) and river sources (white arrow)

640 into these zones are shown. 
643 Table 1: Summary of voyages to the Gulf of Carpentaria and parameters measured on 644 each voyage. SIA $=$ stable isotope analysis, $\mathrm{POM}=$ particulate organic matter, $645 \quad \mathrm{w} / \mathrm{c}=$ water column.

646

\begin{tabular}{|c|c|c|c|c|}
\hline Voyage & Date & Region & $\begin{array}{l}\text { Depth } \\
\text { (m) }\end{array}$ & Parameters (\# stations) \\
\hline \multirow[t]{5}{*}{1} & \multirow[t]{5}{*}{$\begin{array}{l}\text { January } \\
2004\end{array}$} & $\begin{array}{l}\text { Albatross Bay } \\
\text { offshore }\end{array}$ & $15-30$ & \multirow{5}{*}{$\begin{array}{l}\text { SIA POM (16) } \\
\text { SIA sediment (16) }\end{array}$} \\
\hline & & $\begin{array}{l}\text { Karumba } \\
\text { offshore }\end{array}$ & $10-25$ & \\
\hline & & Mornington Is. & $35-40$ & \\
\hline & & Vanderlins & $40-50$ & \\
\hline & & Groote Eylandt & $35-40$ & \\
\hline 2 & $\begin{array}{l}\text { February } \\
2005\end{array}$ & Albatross Bay & $7-10$ & $\begin{array}{l}\text { SIA POM (4) } \\
\text { SIA sediment (4) } \\
\text { SIA infauna (4) }\end{array}$ \\
\hline \multirow[t]{3}{*}{3} & \multirow{3}{*}{$\begin{array}{l}\text { February - } \\
\text { March } 2005\end{array}$} & Mornington Is. & $35-40$ & \multirow{3}{*}{$\begin{array}{l}\text { SIA POM (10) } \\
\text { SIA sediment (48) } \\
\text { SIA infauna (9) } \\
\text { Denitrification (29) } \\
\text { N fixation w/c (1) } \\
\text { Dissolved nutrients (123) } \\
\text { Physico-chem profile (123) } \\
\text { Chlorophyll a (9) }\end{array}$} \\
\hline & & Vanderlins & $40-50$ & \\
\hline & & Groote Eylandt & $35-40$ & \\
\hline
\end{tabular}


Table 2: Mean $( \pm \mathrm{SD})$ concentrations for physico-chemical parameters and nutrient 648 rate measurements through the water column in February/March 2005 in the Gulf of 649 Carpentaria. DIN $=$ dissolved inorganic $\mathrm{N}$.

650

\begin{tabular}{|c|c|c|}
\hline Parameter & Value (SD) & \# Stations \\
\hline Chlorophyll $a\left(\mu \mathrm{g} \mathrm{L}^{-1}\right)$ & $0.80(0.45)$ & 9 \\
\hline Oxygen $\left(\mathrm{mg} \mathrm{L}^{-1}\right)$ & $5.98(0.37)$ & 123 \\
\hline Water temperature $\left({ }^{\circ} \mathrm{C}\right)$ & $30.61(0.36)$ & 123 \\
\hline Denitrification rate $\left(\mu \mathrm{mol} \mathrm{m} \mathrm{m}^{-2} \mathrm{~h}^{-1}\right)$ & $0.27(1.39)$ & 29 \\
\hline
\end{tabular}

651

652

653 
Table 3: Pools (MT N) and fluxes (MT N y ${ }^{-1}$ ) of $\mathrm{N}$ in the Gulf of Carpentaria

\begin{tabular}{|l|l|l|l|}
\hline Parameter & $\begin{array}{r}\text { Pools } \\
(\mathbf{M T})\end{array}$ & $\begin{array}{c}\text { Fluxes } \\
\mathbf{M T ~ y}^{-1} \text { ) }\end{array}$ & \\
\hline Pools & & & Source \\
\hline Nitrate & 75 & & $\begin{array}{l}\text { Rothlisberg et al. (1989), Rothlisberg et al. (1994), Burford and Rothlisberg (1999), } \\
\text { Burford et al. (this study) }\end{array}$ \\
\hline Ammonium & 24 & & Burford et al. (this study) \\
\hline Regenerated inputs & & & \\
\hline Nitrate uptake - phytoplankton & & 390 & Burford and Rothlisberg (1999) \\
\hline Ammonium uptake - phytoplankton & & 260 & Burford and Rothlisberg (1999) \\
\hline Sediment ammonium flux & & $?$ & \\
\hline New inputs & & & Burford et al. (this study) \\
\hline N fixation - Trichodesmium & & 290 & Moriarty and O'Donohue (1993), Pollard unpubl. data \\
\hline N fixation - seagrass beds & & 47 & A. Brooks unpubl. Data, M. Burford unpubl. data \\
\hline N inputs - rivers & & 42 & \\
\hline Outputs & & 11 & Burford et al. (this study) \\
\hline Denitrification & & & \\
\hline
\end{tabular}


Fig. 1

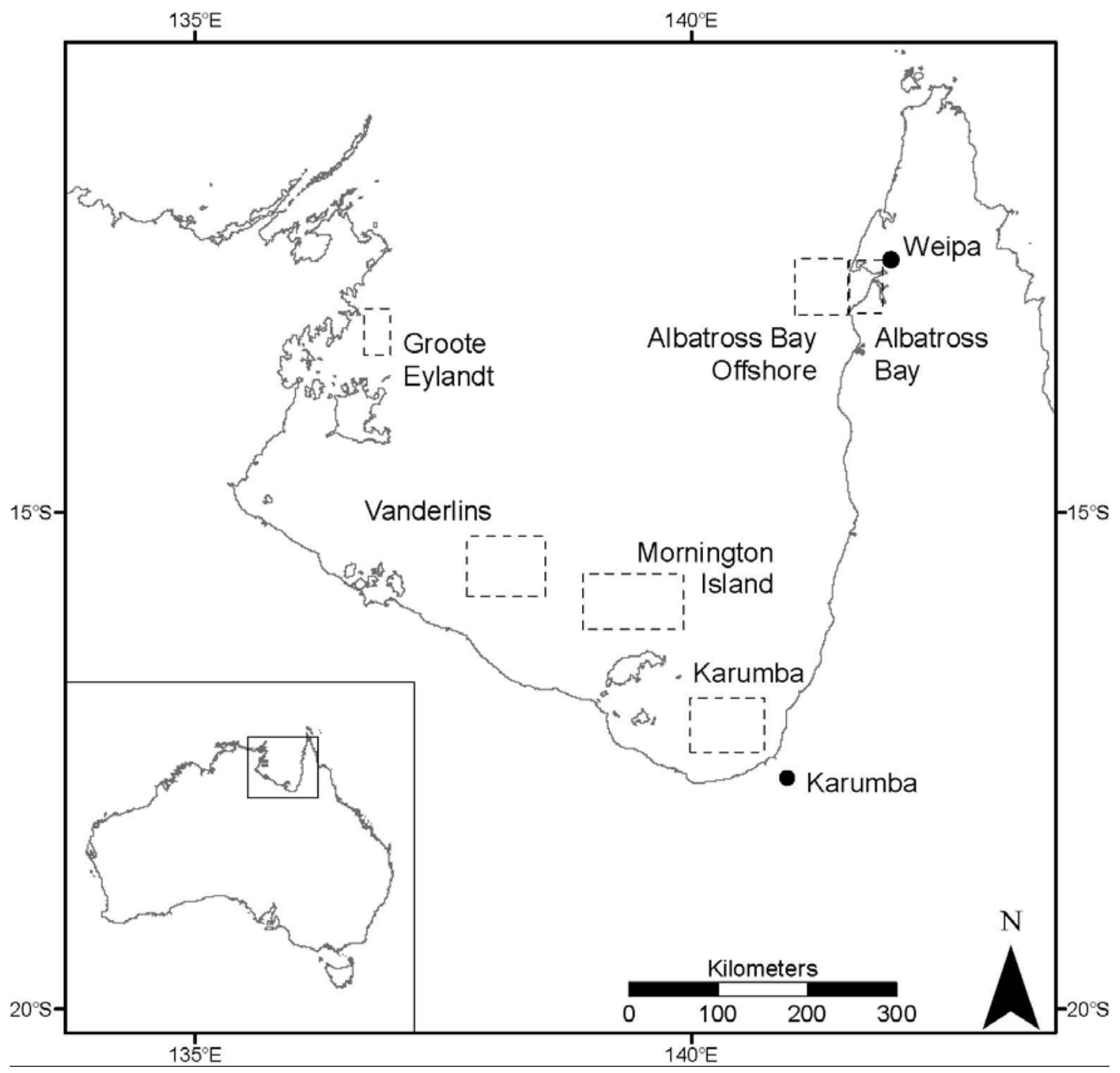




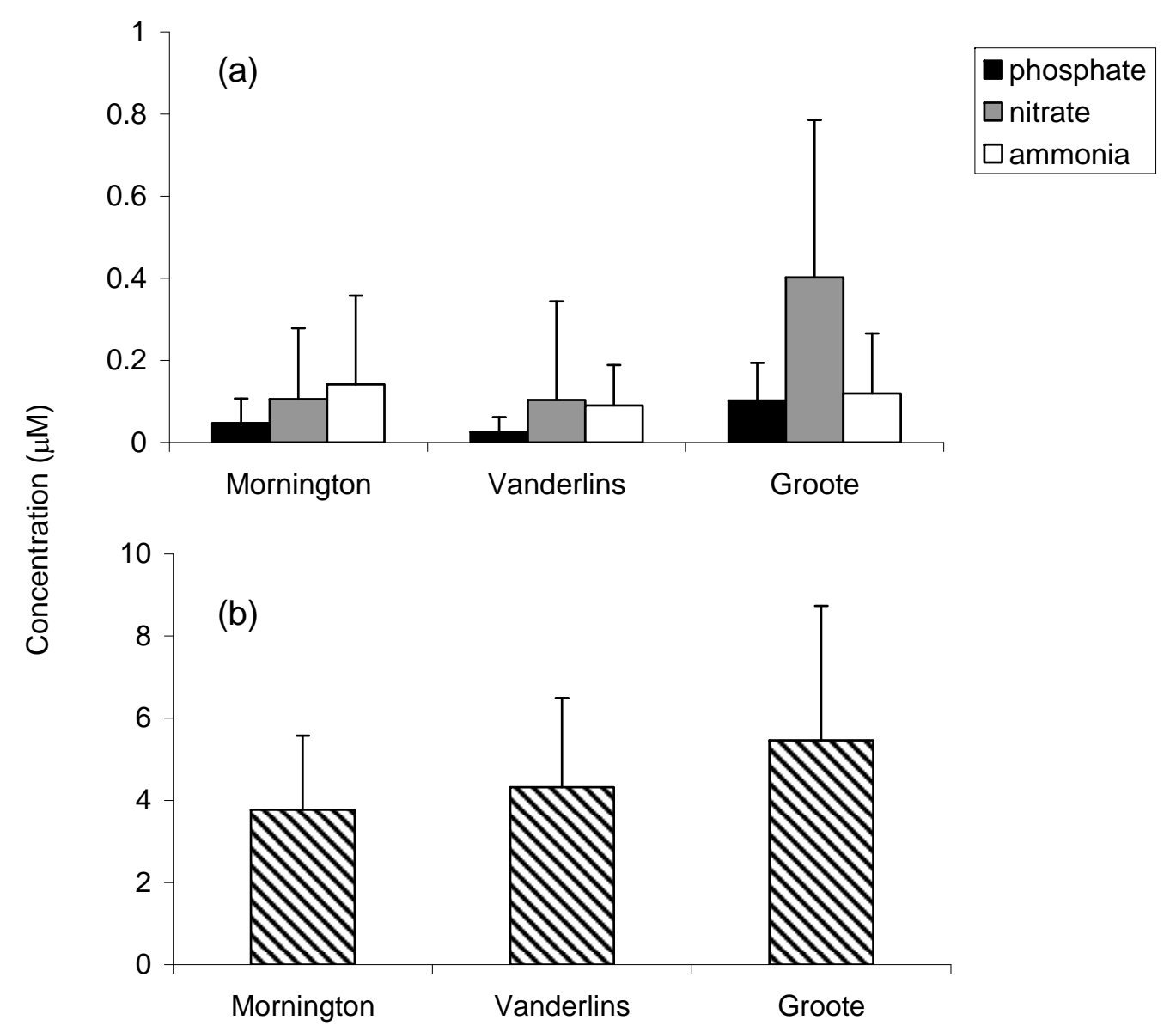

Fig. 2 
Fig. 3

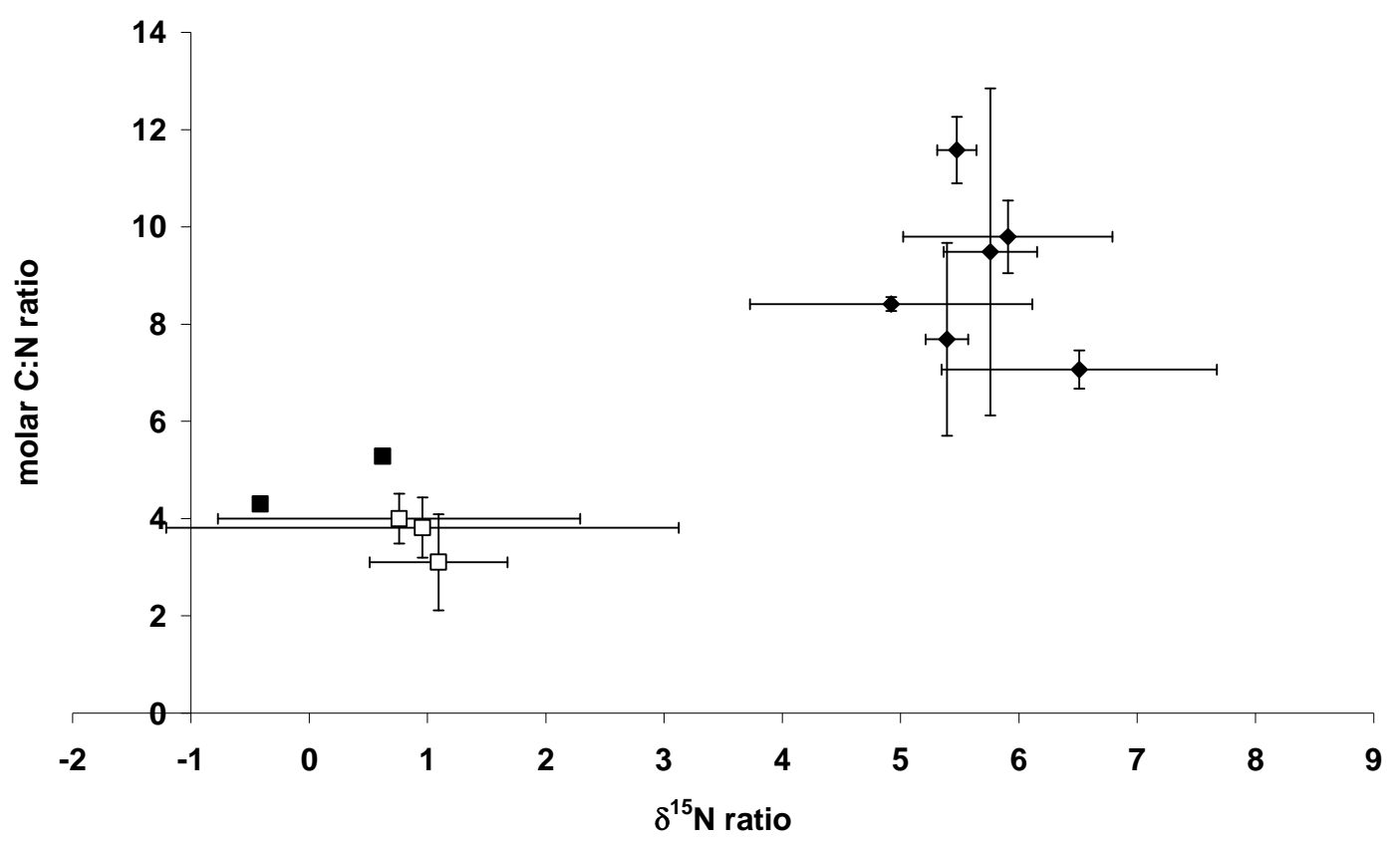


Fig. 4




Fig. 5

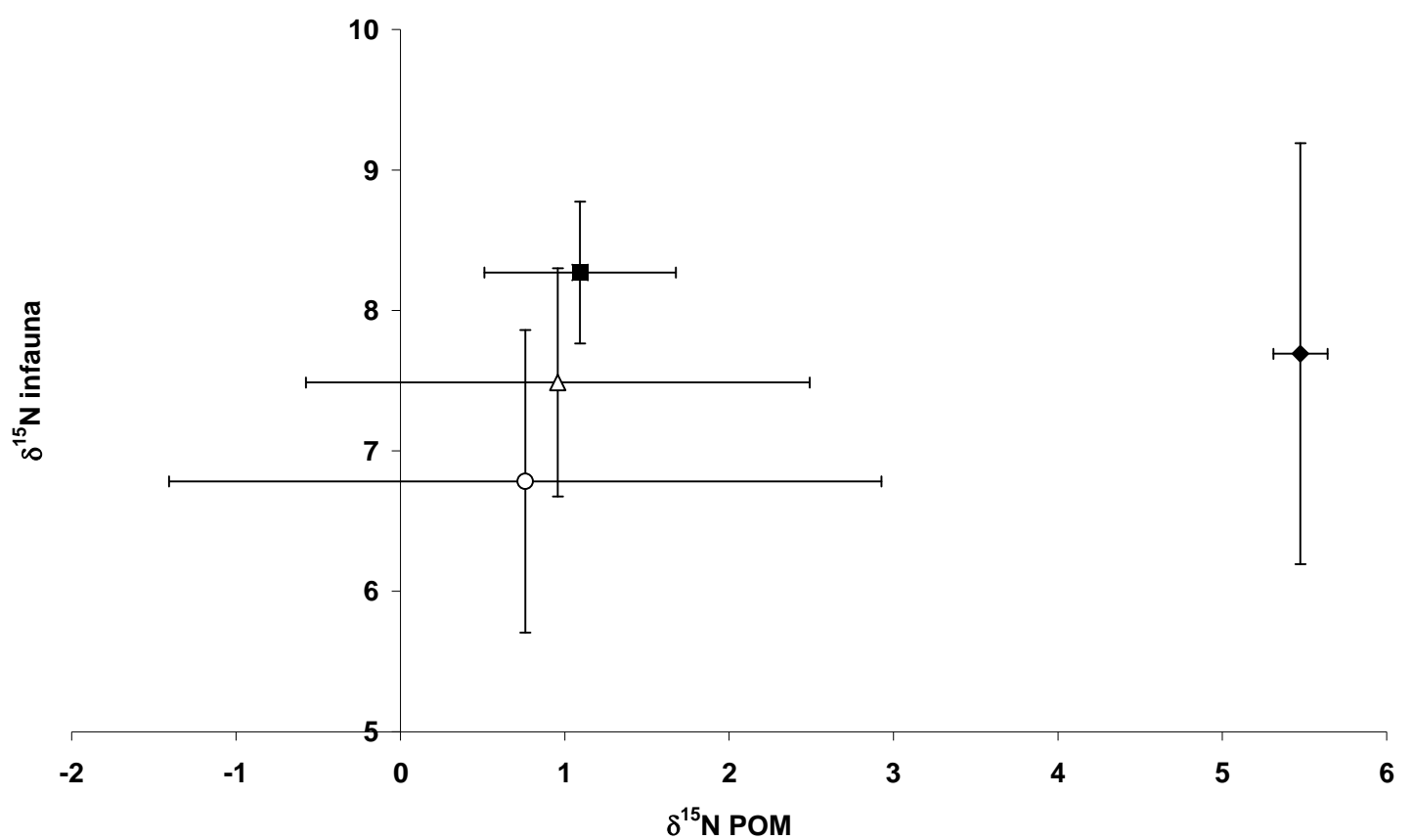


Fig. 6

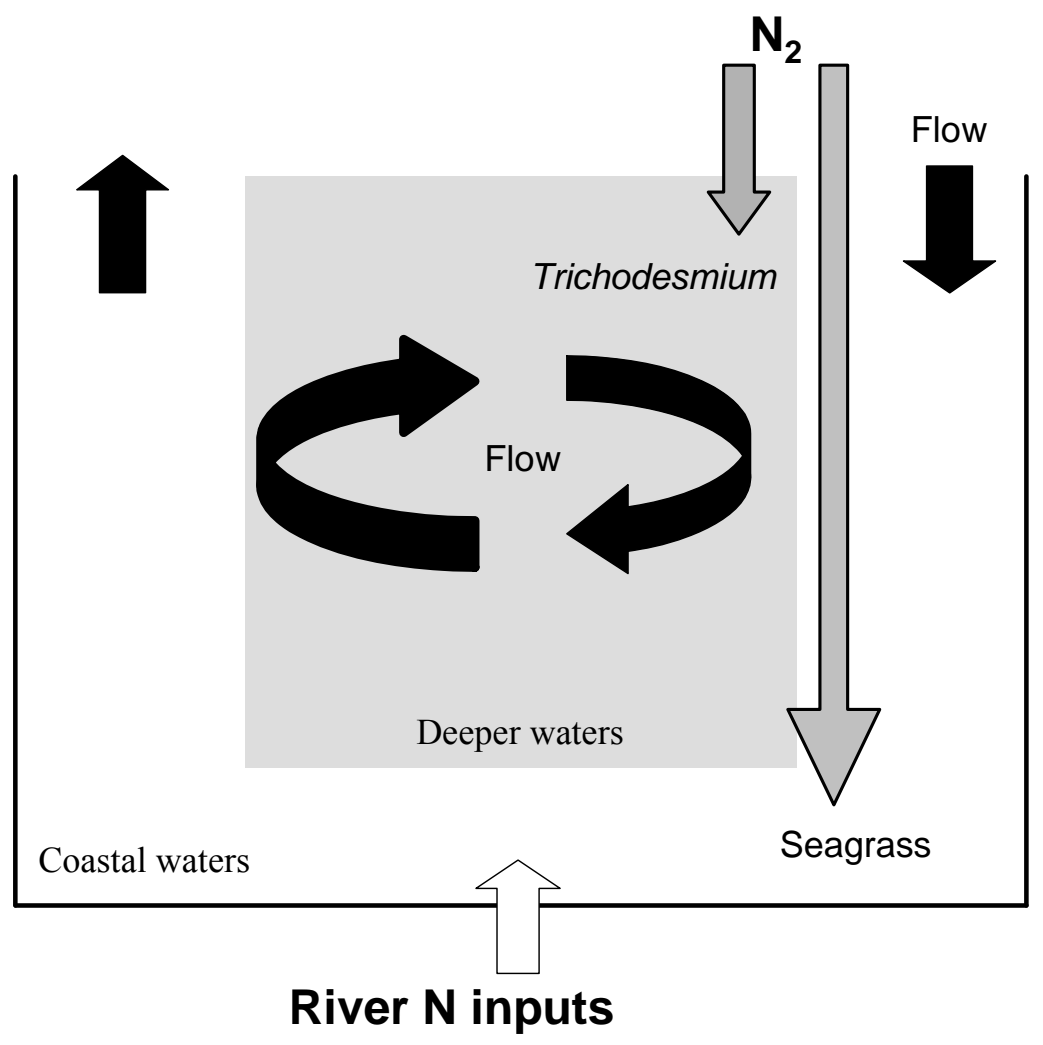

